\title{
The Influence of Social Network Attributes, Flows, Trust, and Electronic Word of Mouth on Social Network Users' Purchase Intentions for Smart Phone Products in Indonesia
}

\author{
${ }^{*}$ Refika Tiara ${ }^{1}$, Andri Ardhiyansyah ${ }^{2}$, Sahid Susilo Nugroho ${ }^{3}$ \\ ${ }^{1}$ Universitas Gadjah Mada, Yogyakarta, Indonesia \\ ${ }^{2}$ Universitas Nusa Putra, Sukabumi, Indonesia \\ ${ }^{3}$ Universitas Gadjah Mada, Yogyakarta, Indonesia \\ *Corresponding author. Email: refikatiara@gmail.com
}

\begin{abstract}
The purpose of this research is to look into the impact of social network features such as flow, trust, and electronic Word-of-Mouth (e-WOM) on the purchase intention of social network users in Indonesia when it comes to smartphone items. The study sampled Indonesian social networking users. Purposive sampling was utilized to acquire data for this study; 200 responses were gathered. The respondents' criterion stipulated that they are social network users who have never sought information about smartphone devices and are 18 years old. The data were gathered through the use of online surveys. Simple linear regression and multiple linear regression were utilized in the analysis. The results of this study show that social network features have a beneficial impact on flow, that social network attributes positively influence e-WOM, that social network attributes positively influence trust, that flow positively influences e-WOM, that trust positively influences e-WOM, that trust positively influences flow, and that e-WOM positively influences purchasing intention. The most significant variable is the effect of social networking on trust. Additionally, EWOM has a significant impact on purchasing intention. Finally, the characteristic with the most negligible influence on electronic word of mouth is the social network attribute.
\end{abstract}

Keywords: Social Network Attribute, Flow, Trust, Electronic Word of Mouth, Smart Phones, Purchase Intention.

\section{BACKGROUND}

The development of internet technology is supported by advances in technology, computers, and telecommunications. The internet can remove limitations by connecting each of its users to a computer or smartphone, commonly known as a virtual world. The development of internet technology makes people obtain information quickly and accurately to support their daily activities and change people's behavior in socializing. The history of the internet began in the 1960s with the development of network experiments conducted by scientists for computer-to-computer communication.

Social networks are a type of technological communication not limited by geography or time [1]. Nodes (individuals or organizations) are joined by one or more various sorts of linkages to build social networks. [2]. Users may upload photos, create blogs, discuss ideas, and link to other websites on social networks. Social networks evolved in lockstep with the internet's growth.

Indonesia is one of the countries where internet technology is advancing at a breakneck pace. According to Kompas daily news, Indonesia's internet users surpassed 202.6 million in early 2021. This figure represents a rise of 15.5 percent, or 27 million persons, over January 2020. Indonesia's overall population is now 274.9 million. This suggests that by early 2021 , internet penetration in Indonesia will reach 73.7 percent. 
The most extensively used social media sites in Indonesia, according to a 2017 analysis by Tech in Asia, include Facebook, Instagram, and Twitter. Indonesia is the third-largest Facebook user country, behind India and the United States. Director of International Information Services at the Directorate General of Information and Public Communication (IKP), stated that Facebook and Instagram were the most frequently visited social media platforms [3].

The advancement of smartphones is inextricably linked to the advancement of internet technologies. Smartphones evolved from mobile phones, which were created in 1973 by Motorola Corp.'s Martin Cooper. 1-G technology is still analog and is referred to as AMPS. In the 1990s, the second generation, or $2 \mathrm{G}$, debuted. In America, $2 \mathrm{G}$ is already utilizing CDMA technology, while in Europe, it is utilizing GSM technology. Generation 3 is commonly known as $3 \mathrm{G}$, and it enables network operators to deliver more extensive coverage to their subscribers, including internet and high-tech video conversations. Three standards govern the world of telecommunications in 3G: Enhanced Data Rates for GSM Evolution (EDGE), Wideband-CDMA, and CDMA 2000. Generation 4, also known as Fourth Generation (4G), is a mobile phone system that utilizes emerging wireless technologies such as wireless broadband (WiBro), 802.16e, CDMA, wireless LAN, and Bluetooth. Many smartphone users and social networks are used by companies and marketers to market and sell their products online. Product marketing online is considered more efficient (cheaper) than promotion through traditional media. Based on a straightforward marketing survey website shows that the cost to reach 2,000 viewers on traditional media reaches USD900 in direct mail, USD500 in magazine advertisements, USD250 in newspaper advertisements, and USD150 in broadcasts, while on the internet media only requires USD75 in social networks and USD50 in search.

As many as 61 percent of urban residents in Indonesia have a smartphone and use it for 5.5 hours a day. Smartphone users typically spend 5.5 hours of their time accessing social media, searching for information, shopping, seeking entertainment, and communicating. According to research by Google and GfK conducted in five cities, namely Jakarta, Bodetabek (Bogor, Depok, Tangerang, Bekasi), Bandung, Semarang, and Surabaya show that city residents can use 16 applications or sites every day. This research shows the increasing importance of smartphones for businesses and content providers to touch consumers. In addition, this research shows that mobile phones have changed the shopping behavior of city dwellers. Users will search and compare information from the internet to finally decide to purchase [4].

Social relations are one of the attributes of social networks. People use social networks to build social relationships, seek entertainment, and gather information. In the business context, the influence of social networking attributes on the flow (attention) of these users has a positive impact on the marketing of products or services. Companies or sellers-market their products on social networks by utilizing the attributes of social networks, namely social relationships that can affect the user's focus of attention. When users can feel the attributes of social networks, it will affect users' full involvement and concentration in digital marketing activities. The attributes of social networks in this study are social relationships. One of the benefits of social networking can improve social relations between users.

Based on the background described above, digital marketing is closely related to electronic word of mouth, which continuously spreads chain messages to everyone-the occurrence of electronic transmission, especially positive ones. The company highly expects this because it can influence the intention of social network users to buy their products. However, there is still a group of people who do not do this electronic word of mouth, someone who conducts electronic word of mouth is influenced by his trust in the social network used, other users' ability on the social network, and the user's experience when accessing social networks. The fact is that not all Indonesians believe in social networks [5]. The 2013 Edelman Trust Barometer research results said that 32 percent of Indonesians still do not believe in social networks [6]. The study conducted by Twitter and Annalect, 40 percent of users claim to have purchased goods online after seeing the object being used and shared by someone on their social media [7]. This needs to be considered by smartphone companies that can influence social network users to buy smartphones. The tight competition of smartphone companies makes companies have to pay attention to the aspects that can influence social network users' purchasing intentions.

\section{LITERATURE REVIEW}

\subsection{Social Networking}

A social network is a collection of people, businesses, and organizations, or other social entities linked by a network of significant social interactions [8]. The advent of the internet has resulted in a new mode of communication, termed collaborative communication, which enables individuals to speak and interact with one another without physically meeting [9]. The development of interactive, 
collaborative communication has resulted in multiuser virtual communities for social networks, dubbed virtual social networks (VSN). This has developed into a critical communication component [10].Virtual social networks establish and sustain social connections between geographically scattered people worldwide. They have grown in importance as a means of communication in today's society. The rise of web 2.0, a user-centered technology, enables the development of enormous and mediated networking opportunities online [11].

Social networks are a type of media that enable people to communicate in cyberspace [12]. Created social networking websites that enable users to register and join in conversing and exchanging resources representing offline relationships or newly formed online ties [1]. Individuals who are members of social networks can build public profiles to share knowledge and user experiences and transmit and receive information about themselves [13]. Social networks, user relationships are based on real-world users, and users must give accurate or current personal information

\subsection{Flow Theory}

Flow is a state of mind in which a person is engaged and concentrated on a task. The current condition is the best state for the wholly absorbed in his work [14]. When a person is in a flow state, they are entirely focused on their actions and experiences, resulting in solid states of mind such as delight and lack of self-awareness. According to researchers, such encounters can entice consumers and significantly impact particular and subsequent behavior [15]. Researchers have discovered that stream experience is a critical predictor of consumer views regarding websites [16], boosting the likelihood of consumers returning to and spending extra time on such websites [17].

The goal of utilizing flow theory is to demonstrate that good electronic word of mouth is a natural outcome of pleasant experiences in social networking activities [18]. Individuals who experience flow, according to flow theory, become more productive and successful. Define flow in terms of seven dimensions: perceived control, temporal distortion, virtual presence, loss of self-awareness, concentration, and loss of awareness and activity [1].

\subsection{Trust}

Trust has long been acknowledged as a critical aspect in determining an internet business's success. Trust is an attitude of optimism and faith that one's vulnerability will not be abused in online risk circumstances [19]. Recent polls indicate that the success of online shopping sites nowadays is inextricably linked to their ability to acquire customers' confidence. When one party trusts another in exchange for the reliability and integrity of another user, trust is formed [18]. Users of social networks in cyberspace who are strangers to one another sometimes confront trust issues. Trust is critical in influencing member behavior in virtual communities because people engage more proactively when they trust their surroundings and fellow members [20].

\subsection{Electronic Word of Mouth}

Electronic word of mouth refers to a good or negative comment about a product or company made on the internet by potential and actual customers [21] in [22]. That word of mouth is a communication method that involves individuals and groups making recommendations for a product or service that collects personal information [23].

When people post about a company's branding, goods, or services on social media platforms, electronic word-of-mouth information might emerge. Additionally, users may unwittingly express preferences for their community, such as being a fan of a brand or submitting photographs that feature a brand without the intention of promotion [22]. Modeled the qualities of reviews that encourage customers to incorporate information into their purchase decisions, notably the timeliness of information, its capacity to be understood, relevance, and quantity [25].

\subsection{Purchase Intention}

Describe purchase intention as a factor that motivates consumers to consider purchasing or to act on purchasing a brand [23]. Consumers' rational purchase decision-making process consists of three stages: cognitive demands, information collection, and purchasing behavior. Researchers think that virtual communities have had a significant impact on consumers' purchasing decisions nowadays [20].

\subsection{The Influence of Social Network Attributes on Flow}

One of the social media's purposes is to establish, maintain, and develop social connections. In this study, social ties are considered the characteristics of social networks. Social interactions developed through social networks can influence how users participate in social network activities referred to as flows. Users that use social media for social interactions will interact with their friends, family, and coworkers, among others. The more social networking qualities (social connections) are used, the more users become absorbed in social networking activities, losing time when accessing these social networks. Users that communicate and exchange information on social 
networks frequently lose track of time and become absorbed in their activities on these networks, leading to the following hypothesis:

H1: Social network attributes have a positive influence on the flow.

\subsection{The Influence of Social Network Attributes on Electronic Word of Mouth}

Interactions and relationships with others have a favorable effect on electronic word of mouth [26]. These encounters frequently involve exchanging information, one of which is product information. Individuals who have a larger number of social media contacts are more inclined to share information and opinions about items or services. Users with broad social networks tend to exchange information or product evaluations more frequently and exercise a more significant impact over other users. The stronger the social link, the more information or product reviews are shared on social media; hence, the following hypothesis is made:

$\mathrm{H} 2$ : Social network attributes have a positive influence on electronic word of mouth.

\subsection{The Influence of Social Network Attributes on Trust}

Demonstrate that social network features affect trust [1]. Social networking is built on sharing material, ideas, images, and music, all of which require trust [26]. Familiarity gained via social interactions fosters trust. Suggest that when individuals engage in cyberspace, we may judge their trustworthiness by examining the consistency of their communications and behavior [1]. When users develop social ties with other users, they trust one another-the more frequent interactions between users, the stronger their trust. Additionally, the more frequently consumers exchange information, the greater their trust. The following assumptions can be derived from this explanation:

H3: Social networks attributes have a positive influence on trust.

\subsection{The Influence of Flow on Electronic Word of Mouth}

The present state is characterized as an experimental situation in which an individual should exert influence over the activities of social network members. The present status has a significant influence on electronic word of mouth on websites (may be applied to social networks) [5]. When users are in flow, they will concentrate on their activity and waste time on social media. Concentrated social network members will supply information or positive opinions regarding items. These users' information or reviews are subsequently shared with other users. The more invested and concentrated people are in their social network activities, the higher their effect on electronic word of mouth. The more involved and focused people are in social network activities, the more likely they are to share and exchange information on products or services on these social networks, as follows:

H4: Flow has a positive influence on electronic word of mouth

\subsection{The Influence of Trust on Electronic Word of Mouth}

Trust influences electronic word of mouth when disseminating information about products and services [26]. In this study, trust is defined as confidence in social networks and the capacity of other users to give product information. Users who trust the social network they use will remain active on it and are more inclined to contribute product information. When a person trusts other users and can communicate product information on social networks, that user tends to perform electronic word-of-mouth. The tendency to share information in virtual communities is considerably enhanced by members' trust in one another [1]. Trust amongst users enhances the likelihood that they would accept peer suggestions [1]. As a result, if a user has a high level of trust and suggests a seller or firm with a good reputation in cyberspace, the user is more likely to believe and accept the information. The more a person trusts the social network on which he or she is logged in, the more information and opinions about the product he or she shares. Similarly, the more users trust other users' abilities, the more frequently these users discuss and exchange information about products and services. The following assumptions can be derived from this explanation:

H5: Electronic word of mouth is influenced positively by trust.

\subsection{The Influence of Trust on Flow}

Research, trust significantly impacts how consumers behave in mobile banking. This impact also extends to social media platforms [27]. Users who experience flow on social media platforms, as long as they trust the platforms they use and the other users with whom they connect on social media platforms. Users who trust the social network they use will quickly feel total involvement and concentration on the social network's activity. Users who have faith in the talents of other users will engage in continuous interaction on social networks, losing sight of time and so spending more time. The more the user's faith in the social network and the capabilities of other users, the 
more concentrated and time-consuming users will be, allowing for the formulation of the hypothesis:

H6: Flow is influenced positively by trust

\subsection{The Influence of Electronic Word of Mouth on Purchase Intention}

Through electronic word of mouth, online groups can affect consumer behavior. Electronic word of mouth is critical in customer decision-making. It may play a critical role throughout the customer decisionmaking, from need identification through postpurchase assessment [1]. Consumer behavior is significantly influenced by electronic word of mouth. Electronic word of mouth refers to a comment made by a consumer who has freely used a product or service (without being paid). The individual's statement is credible. Electronic word of mouth has a beneficial effect on customers' purchase intentions. Users that obtain knowledge or favorable evaluations about a product will purchase it [28].
Additionally, when a user sees inadequate evaluations about a product or service, that user may decide not to purchase the product or service. Indicated that electronic word of mouth dramatically affects purchase intention [29]. Electronic word of mouth that is rational, compelling, and based on product facts will positively affect purchase intention. The volume of electronic word of mouth also influences customer purchasing intentions positively [30]. The more electronic word-of-mouth social network users generate, the more they will impact social network members' purchasing intentions for particular items. The following assumptions can be derived from this explanation:

H7: The influence of electronic word of mouth on purchase intent is good.

\subsection{Research Model}

The model used in this research replicates work done previously [1]. The researcher proposes the following research paradigm based on the prior study:

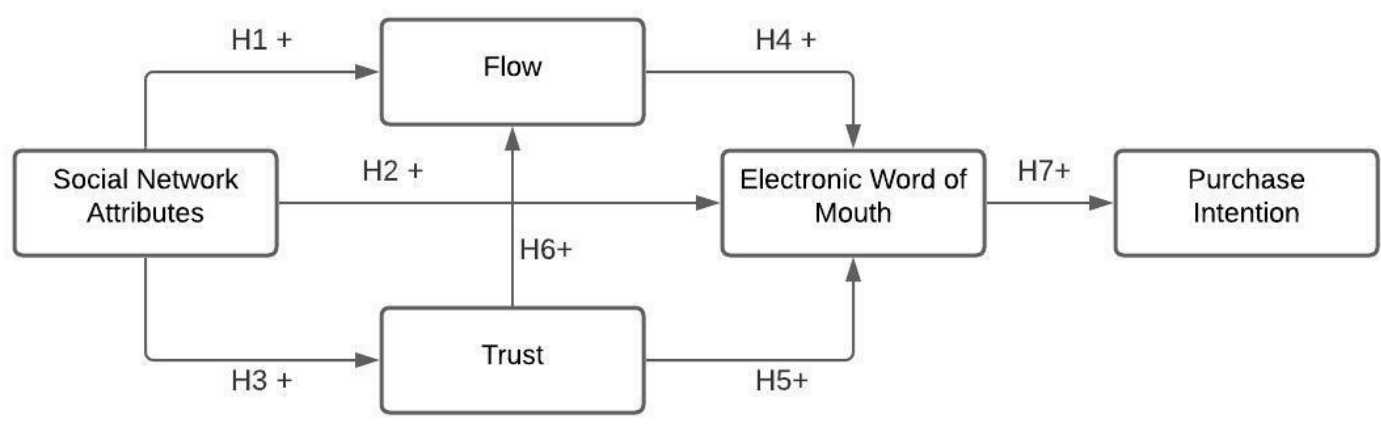

Figure 1. Research Model

\section{RESEARCH METHODS}

\subsection{Research Strategy}

This research uses the quantitative research strategy in conjunction with a survey technique. This quantitative methodology is used to evaluate theories and models that attempt to explain consumer behavior and determine the links between the model and the survey method. The objective of conducting a survey is to collect data that can be compared between various subgroups of the sample to ascertain similarities and differences. The survey is being undertaken to ascertain the circumstances and effect of the factors being examined.

\subsection{Sampling Method}

This study used non-probability sampling, which means that no sample (population element) has an equal chance of being chosen as a sample. Purposive sampling (judgmental sampling) is utilized. The sample is chosen based on predetermined criteria relevant to the study topic [31]. The sample's characteristics are determined by criteria, including social media platforms such as Facebook, Instagram, Twitter, Path, Youtube, and Kaskus. They have received or looked for smartphone product information on one of these platforms.

\section{RESULTS AND DISCUSSION}

\subsection{Research Data Quality}

The normality and multicollinearity tests were performed to determine the data quality in this investigation. SPSS for Windows version 24 was used to test for normality and multicollinearity in this study. 


\section{a) Normality test}

The Kolmogorov-Smirnov One-Sample analysis was employed to determine normality in this study, conducted using SPSS for Windows version 24 software. The normality test in this study will determine the Kolmogorov-Smirnov significant value. If the significance value is greater than 0.05 , the data distribution is considered, test findings are shown in Table 1.

Table 1. Normality of the Test Results

Kolmogorov-Smirnov. One-Sample Test Data

\begin{tabular}{|c|c|c|c|c|c|c|}
\hline & N & $\begin{array}{c}\text { Social } \\
\text { Networking } \\
\text { Attributes }\end{array}$ & Flow & Trust & $\begin{array}{c}\text { Electronic } \\
\text { Word of } \\
\text { Mouth }\end{array}$ & $\begin{array}{c}\text { Purchase } \\
\text { Intention }\end{array}$ \\
\hline \multicolumn{2}{|c|}{} & 200 & 200 & 200 & 200 & 200 \\
\hline $\begin{array}{c}\text { Normal } \\
\text { Parameter } \\
\text { a.b }\end{array}$ & Average & 22,94 & 21,9 & 25,03 & 19,66 & 9,71 \\
\cline { 2 - 7 } & St. deviation & 4,111 & 4,315 & 4,356 & 5,407 & 2,699 \\
\hline $\begin{array}{c}\text { Difference } \\
\text { Very } \\
\text { Extreme }\end{array}$ & Absolut & 0,151 & 0,082 & 0,128 & 0,094 & 0,106 \\
\cline { 2 - 7 } & Posiif & 0,088 & 0,051 & 0,078 & 0,055 & 0,098 \\
\hline \multicolumn{2}{|c|}{ Statistic test } & $-0,151$ & $-0,082$ & $-0,128$ & $-0,094$ & $-0,106$ \\
\hline \multicolumn{2}{|c|}{ Asymp. Sig. (2-tailed) } & 0,151 & 0,082 & 0,128 & 0,094 & 0,106 \\
\hline
\end{tabular}

a. Test distribution is Normal.

b. Calculated from data.

The Asymp value is determined by doing a one-sample Kolmogorov test on the data. Sig (2-tailed) is less than 0.05 for social network attribute variables such as current, trust, electronic word of mouth, and my intention. Sig. Asymptotic value (2-tailed) During the Asymptote value, the attribute variables social networking, trust, electronic word of mouth, and intention are all set to 0.000 . The current variable's Sig. (2-tailed) value is 0.002 . This demonstrates that none of the variables are regularly distributed.

\section{b) Multicollinearity Test}

According to the calculations carried out with the SPSS for Windows version 24 program, the multicollinearity test can be seen by referring to the VIF value less than ten and tolerance (tolerance) more than 0.1 . The results of the multicollinearity test can be seen from the tolerance and VIF values are presented in table 2 .

Table 2. Multicollinearity Test Results

\begin{tabular}{|c|c|c|}
\hline \multirow{2}{*}{ Variables \& Regression Models } & Collinearity Statistics \\
\cline { 2 - 3 } & Tolerance & VIF \\
\hline Social Network Attributes (Model 1) & 0,646 & 1,548 \\
\hline Social Network Attributes (Model 2) & 0,620 & 1,613 \\
\hline Flow & 0,829 & 1,207 \\
\hline Trust & 0,646 & 1,612 \\
\hline \multicolumn{2}{|c|}{ Dependent Variable: Purchase Intention } \\
\hline
\end{tabular}

The computation of the Variance Inflation Factor (VIF) reveals that no independent variable has a VIF value greater than ten. According to table 2, the results of the tolerance value computation indicate that no independent variable has a tolerance value less than 0.1 . The tolerance value for the social network attribute in model 1 is 0.646 , the tolerance value for the social network attribute in model 2 is 0.620 , the tolerance value for current is 0.829 , and the tolerance value for trust is 0.646 . In model 1 , the social network attribute has a VIF value of 
1.548; in model 2, the social network attribute has a VIF value of 1.613; in model 3, the current has a VIF value of 1.207; and trust has a VIF value of 1.612. Thus, it can be stated that the regression model with the social network, current, and trust attribute variables does not exhibit multicollinearity.

\section{c) Correlation Analysis Between Variables}

Table 3. Pearson Correlation Test Results

Table 3. Pearson Correlation Test Results
\begin{tabular}{|c|c|c|c|c|c|}
\hline & $\begin{array}{c}\text { Social } \\
\text { Networking } \\
\text { Attributes }\end{array}$ & Flow & Trust & $\begin{array}{c}\text { Electronic } \\
\text { Word of } \\
\text { Mouth }\end{array}$ & $\begin{array}{c}\text { Purchase } \\
\text { Intention }\end{array}$ \\
\hline $\begin{array}{c}\text { Social } \\
\text { Networking } \\
\text { Attributes }\end{array}$ & 1 & $0,370\left(^{* *}\right)$ & $0,595\left(^{(*}\right)$ & $0,460\left(^{* *}\right)$ & $0,370\left(^{* *}\right)$ \\
\hline Flow & $0,370\left(^{* *}\right)$ & 1 & $0,369\left(^{* *}\right)$ & $0,429\left(^{* *}\right)$ & $0,406\left(^{* *}\right)$ \\
\hline Trust & $0,595\left(^{* *}\right)$ & $0,369\left(^{* *}\right)$ & 1 & $0,512\left(^{* *}\right)$ & $0,477\left(^{* *}\right)$ \\
\hline $\begin{array}{c}\text { Electronic } \\
\text { Word of } \\
\text { Mouth }\end{array}$ & $0,469\left(^{* *}\right)$ & $0,429\left(^{* *}\right)$ & $0,512\left(^{(*}\right)$ & 1 & $0,490\left(^{* *}\right)$ \\
\hline $\begin{array}{c}\text { Purchase } \\
\text { Intention }\end{array}$ & $0,370\left(^{* *}\right)$ & $0,406\left(^{* *}\right)$ & $0,477\left(^{(*}\right)$ & $0,490\left(^{* *}\right)$ & 1 \\
\hline
\end{tabular}

** Correlation is significant at the 0.01 level (2-tailed).

\subsection{Hypothesis test}

Based on the results of both simple and multiple linear regression analyses, it can be seen whether the hypothesis proposed by this study is supported by the regression results of this study. The following is an explanation of the results of testing the first hypothesis to the seventh hypothesis.

\section{a) First Hypothesis}

The first hypothesis advanced in this study is that social network properties have a beneficial influence on flow. The findings of testing the first hypothesis indicate that social network properties have a positive and substantial effect on the flow, supporting the first hypothesis. According to the regression analysis results, the social network attribute variable was found to have a value of 0.233 with a significance level of 0.004 .

b) Second Hypothesis

The second hypothesis advanced in this study is that social networking characteristics beneficially influence electronic word of mouth. The regression analysis revealed that the social network attribute variable had a value of 0.183 and a 0.013 significance level. The results of the second hypothesis testing, indicating social networking characteristics have a positive and substantial influence on electronic word of mouth, are accepted as supporting the second hypothesis.
According to table 4.4, there is a substantial connection between variables at the 0.01 level of significance. The significance value and asterisk indicate that the Pearson correlation coefficient for each variable includes an asterisk, indicating a significant correlation between the variables.

\section{c) Third Hypothesis}

The third hypothesis advanced in this study is that social network characteristics positively influence trust. The social network attribute variable has a value of 0.595 with a significance level of 0.000 based on validated regression analysis. The findings of the third hypothesis, that social network traits have a positive and substantial effect on trust, support the third hypothesis.

d) Fourth Hypothesis

The fourth hypothesis is that flow has a beneficial effect on electronic word of mouth. The regression analysis revealed that the current variable has a value of 0.246 with a 0.000 significance level. The fourth hypothesis is supported by testing that flow has a favorable and substantial influence on electronic word of mouth.

e) Fifth Hypothesis

The fifth premise of the study is that trust has a positive impact on electronic word of mouth. The regression analysis revealed that the confidence variable had a value of 0.313 with a 0.000 significance level. The findings of the fifth hypothesis, that trust has a positive and substantial influence on electronic word of mouth, corroborate the fifth hypothesis.

f) Sixth Hypothesis 
The study's sixth hypothesis is that trust has a beneficial effect on currents. The regression analysis revealed that the confidence variable had a value of 0.231 with a 0.005 significance level. The findings of the sixth hypothesis test indicating that trust has a positive and substantial influence on the flow are accepted as supporting the sixth hypothesis.

g) Seventh Hypothesis

The seventh hypothesis advanced in this study is that electronic word of mouth favors purchasing intentions. The regression analysis findings indicated that the electronic word-of-mouth variable had a value of 0.49 and a 0.000 significance level. The seventh hypothesis is approved for testing, indicating that Electronic word of mouth has a significant and favorable impact on purchase intent.

\subsection{Summary of Hypothesis Test Results}

The researcher describes the outcomes of the hypothesis testing in this study using the research model and the accompanying summary table of hypothesis test results.

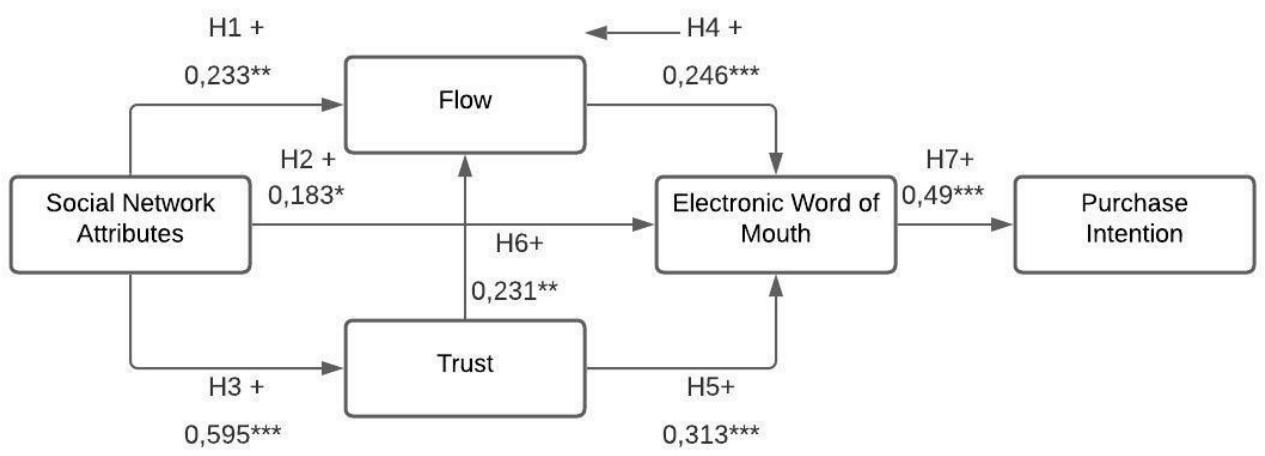

Figure 2. Research Model after performing Regression Calculations

Figure 2 shows that the first hypothesis is that the attribute variable social networking has a positive effect on the flow variable with $1=0.233$ and $=0.004$. The second hypothesis is that the social network attribute variable positively affects electronic word of mouth with $2=0.183$ and $=0.013$. The third hypothesis is that the social network attribute variable positively affects trust with $3=0.595$ and $=0.000$. The fourth hypothesis is that the current variable positively affects electronic communication with $4=0.246$ and
$=0.000$. The fifth hypothesis is that the trust variable positively affects electronic word of mouth with $5=$ 0.313 and $=0.000$. The sixth hypothesis is that the trust variable positively affects the flow variable with $6=$ 0.231 and $=0.005$. The seventh hypothesis is that the electronic word of mouth variable positively affects the purchase intention variable $7=0.49$ and $=0.000$. Table 4 summarizes the findings of the overall hypothesis test.

Table 4. Results of Hypothesis Testing

\begin{tabular}{|l|c|c|c|}
\hline \multicolumn{1}{|c|}{ Hypothesis } & Coefficient $(\beta)$ & Sig. $(\rho)$ & Description \\
\hline $\begin{array}{l}\text { H1: Social network attributes have a positive } \\
\text { influence on the flow. }\end{array}$ & 0,233 & 0,004 & Accepted \\
\hline $\begin{array}{l}\text { H2: Social network attributes have a positive } \\
\text { influence on electronic word of mouth. }\end{array}$ & 0,183 & 0,013 & Accepted \\
\hline $\begin{array}{l}\text { H3: Social networks attributes have a positive } \\
\text { influence on trust. }\end{array}$ & 0,595 & 0,000 & Accepted \\
\hline $\begin{array}{l}\text { H4: Flow has a positive influence on electronic } \\
\text { word of mouth. }\end{array}$ & 0,246 & 0,000 & Accepted \\
\hline $\begin{array}{l}\text { H5: Trust has a positive influence on electronic } \\
\text { word of mouth. }\end{array}$ & 0,313 & 0,000 & Accepted \\
\hline
\end{tabular}




\begin{tabular}{|l|c|c|c|} 
H6: Trust has a positive influence on flow. & 0,231 & 0,005 & Accepted \\
\hline $\begin{array}{l}\text { H7: Electronic word of mouth has a positive } \\
\text { influence on purchase intention. }\end{array}$ & 0,49 & 0,000 & Accepted \\
\hline
\end{tabular}

\section{CONCLUSION}

It can be concluded, based on the conclusions of the prior chapter's research and debate, that: The social networks attributes have a positive and substantial influence on the flow. The stronger the social connection between social network members, the more attention and time the user devotes to their social network activity. Social networking attributes have a substantial favorable effect on electronic word of mouth. The stronger the social bond between social network members, the more information will be exchanged, and electronic word-of-mouth behavior will occur on the social network. Social network attributes have a favorable and substantial influence on trust. The stronger the social relationships between users, the more trust people have in the social network they use and other users' ability on the social network. Flow has a measurable favorable impact on electronic word of mouth.

The more focused or concentrated users are, and the more time they spend on social media, the more likely they are to post favorable reviews and discuss specific product brands. Electronic word of mouth is influenced positively and significantly by the trust. The more faith users have in social networks. The capacity of other users to contribute positive information or reviews about smartphone product brands on social media, the more positive information or reviews users will provide about smartphone product brands on social media. Trust has a substantial favorable influence on the flow. The more the user's faith in the social network he uses and the talents of other users on the social network, the more focused he is on his social network activities. The user loses track of time when visiting the social network. Electronic word of mouth has a substantial beneficial impact on purchasing intention.

\section{REFERENCES}

[1] M. Mortazavi, M. R. Esfidani, and A. S. Barzoki, “Influencing VSN users' purchase intentions The roles of flow, trust and eWOM," J. Res. Interact. Mark., vol. 8, no. 2, pp. 102-123, 2014, doi: 10.1108/JRIM-082013-0057.

[2] L. S. L. Lai and E. Turban, "Groups formation and operations in the web 2.0 environment and social networks," Gr. Decis. Negot, vol. 17, no. 5, pp. 387-402, 2008, doi:

\subsection{7/s10726-008-9113-2.}

[3] Asosiasi Penyelenggara Jasa Internet Indonesia, "Laporan Survei Internet APJII 2019 - 2020," Jakarta, 2020. [Online]. Available: https://apjii.or.id/survei.

[4] B. Indonesia, "Tren Sosial: Warga kota di Indonesia 'mengakses ponsel 5,5 jam per hari," BBC News Indonesia, 2015. https://www.bbc.com/indonesia/majalah/201 5/09/150903_trensosial_google.

[5] A. O'Cass and J. Carlson, "Examining the effects of website-induced flow in professional sporting team websites," Internet Res., vol. 20, no. 2, pp. 115-134, 2010, doi: $10.1108 / 10662241011032209$.

[6] A. News, "Riset: tingkat kepercayaan pada media di Indonesia tinggi," Antara News, 2013.

https://www.antaranews.com/berita/356063/ri set-tingkat-kepercayaan-pada-media-diindonesia-tinggi.

[7] W. D. Putri, "Media Sosial Lebih Pengaruhi Tingkat Kepercayaan Dibanding Pikiran," Republika,

2016. https://www.republika.co.id/berita/trendtek/in ternet/16/05/17/o7bboq359-media-sosiallebih-pengaruhi-tingkat-kepercayaandibanding-pikiran.

[8] K. Levy, "Consumer decision making and word of mouth communication," University of Waterloo, 2012.

[9] A. L. Jepsen, "Information search in virtual communities: Is it replacing use of off-line communication?," J. Mark. Commun., vol. 12, no. 4, pp. 247-261, 2006, doi: $10.1080 / 13527260600694308$.

[10] B. J. Koh, Y.-G. Kim, B. Butler, and G.-W. Bock, "Encouraging Participation in Virtual Communities," Commun. ACM, vol. 50, no. 2, pp. 1-23, 2007.

[11] S. Sangwan, C. Guan, and J. A. Siguaw, "Virtual Social Networks," Int. J. Virtual Communities Soc. Netw., vol. 1, no. 1, pp. 113, 2009, doi: 10.1057/9780230250888.

[12] J. Coons and S.-L. S. Chen, "Social Network Analysis For Facebook: Locating Cliques And 
Visualizing Sociability," Symb. Interact. New Soc. Media, vol. 43, pp. 43-61, 2014.

[13] C. M. K. Cheung, P. Y. Chiu, and M. K. O. Lee, "Online social networks: Why do students use facebook?," Comput. Human Behav., vol. 27, no. 4, pp. 1337-1343, 2011, doi: 10.1016/j.chb.2010.07.028.

[14] M. Csikszentmihalyi, Flow and the Foundations of Positive Psychology. London: Claremont Graduate University, 2014.

[15] T. P. Novak, D. L. Hoffman, and Y. F. Yung, "Measuring the customer experience in online environments: A structural modeling approach," Mark. Sci., vol. 19, no. 1, pp. 2242, 2000, doi: 10.1287/mksc.19.1.22.15184.

[16] C. Mathwick and E. Rigdon, "Play, flow, and the online search experience," J. Consum. Res., vol. 31, no. 2, pp. 324-332, 2004, doi: $10.1086 / 422111$.

[17] S. Kabadayi and R. Gupta, "Website loyalty: an empirical investigation of its antecedents," Int. J. Internet Mark. Advert., vol. 2, no. 4, pp. 321-345, 2005, doi: 10.1504/IJIMA.2005.008105.

[18] A. S. Noori, K. F. Hashim, and S. A. M. Yusof, "Continuous use of social commerce: Its conceptual relation with E-WOM, commitment and trust," Int. Rev. Manag. Mark., vol. 6, no. S7, pp. 226-230, 2016, doi: 10.1063/1.4960935.

[19] J. U. Kim, W. J. Kim, and S. C. Park, "Consumer perceptions on web advertisements and motivation factors to purchase in the online shopping," Comput. Human Behav., vol. 26, no. 5, pp. 1208-1222, 2010, doi: 10.1016/j.chb.2010.03.032.

[20] Y. Lu, L. Zhao, and B. Wang, "From virtual community members to $\mathrm{C} 2 \mathrm{C}$ e-commerce buyers: Trust in virtual communities and its effect on consumers' purchase intention," Electron. Commer. Res. Appl., vol. 9, no. 4, pp. 346-360, 2010, doi: 10.1016/j.elerap.2009.07.003.

[21] T. Hennig-Thurau, K. P. Gwinner, G. Walsh, and D. D. Gremler, "Electronic word-ofmouth via consumer-opinion platforms: What motivates consumers to articulate themselves on the Internet?," J. Interact. Mark., vol. 18, no. 1, pp. 38-52, 2004, doi: 10.1002/dir.10073.

[22] I. Erkan and C. Evans, "The influence of eWOM in social media on consumers' purchase intentions: An extended approach to information adoption," Comput. Human Behav., vol. 61, pp. 47-55, 2016, doi: 10.1016/j.chb.2016.03.003.

[23] P. Kotler and K. L. Keller, Marketing Management. Upper Saddle River. New Jersey: Pearson Education, Inc., 2016.

[24] J. A. Bargh and K. Y. A. McKenna, "The Internet and social life," Annu. Rev. Psychol., vol. 55, pp. 573-590, 2004, doi: 10.1146/annurev.psych.55.090902.141922.

[25] R. Filieri and F. McLeay, "E-WOM and Accommodation: An Analysis of the Factors That Influence Travelers' Adoption of Information from Online Reviews," J. Travel Res., vol. 53, no. 1, pp. 44-57, 2014, doi: $10.1177 / 0047287513481274$.

[26] A. M. Soares, J. C. Pinho, and H. Nobre, "From Social to Marketing Interactions: The Role of Social Networks," J. Transnatl. Manag., vol. 17, no. 1, pp. 45-62, 2012, doi: 10.1080/15475778.2012.650085.

[27] T. Zhou, "Examining mobile banking user adoption from the perspectives of trust and flow experience," Inf. Technol. Manag., vol. 13, no. 1, pp. 27-37, 2012, doi: 10.1007/s10799-011-0111-8.

[28] N. Sa'ait, A. Kanyan, and M. F. Nazrin, "The Effect of E-WOM on Customer Purchase Intention," Int. Acad. Res. J. Soc. Sci., vol. 2, no. 1, pp. 73-80, 2016.

[29] Y. Y. Y. Chan and E. W. T. Ngai, "Conceptualising electronic word of mouth activity: An input-process-output perspective," Mark. Intell. Plan., vol. 29, no. 5, pp. 488-516, 2011, doi: $10.1108 / 02634501111153692$.

[30] T. G. Theodore and W. D. Menzie, "Fluorinedeficient porphyry molybdenum deposits in the western North America Cordillera.," Proceedings, Sixth IAGOD Symp., vol. 9026, no. 97, pp. 463-470, 1984.

[31] D. R. Cooper and P. S. Schindler, Business Research Methods. McGraw-Hill Inc., 2014. 